\title{
FLAUBERT E O CREPÚSCULO DO SUJEITO:UMA ANÁLISE DO CONTO "UM CORAÇÃO SIMPLES" 1
}

\author{
Luciana Dadico
}

Resumo: A literatura francesa e mundial passaram por uma enorme transformação ao longo do século XIX. A primorosa escrita de Flaubert é, para além de sua importância estética, reveladora de um novo modo de se escrever, ler e representar o homem no mundo moderno. $O$ cuidado na construção do texto, a utilização de imagens plásticas e figuras de linguagem, ao mesmo tempo em que o narrador torna-se invisível no emprego do discurso indireto livre são característicos da escrita flaubertiana. O autor apresenta-nos em “Um coração simples" um "retrato" de Félicité, mulher pobre do interior da França, modelo virtuoso de uma ética evanescente. Ao acompanhar, por meio do conto, os passos e desventuras de Felicité, sob as lentes deste novo narrador, buscamos evidenciar as condições que circundam o aparecimento de um olhar científico-objetivo para a subjetividade humana, logo transformada em objeto de uma nascente Psicologia.

Palavras-chave: Subjetividade.Teoria literária. Literatura francesa. Realismo. Leitura.

1 Este trabalho foi realizado com apoio financeiro do Conselho Nacional de Pesquisa (CNPq). A redação original do artigo data de 2008, tendo recebido correções e adequações no ano de 2009, para esta publicação.

Agradeço o incentivo e a leitura generosamente atenta da Prof. Dra. Iray Carone, fundamentais para que este texto viesse a ser publicado. Agradeço também os comentários precisos do Prof. Carlo Ginzburg, destacando os cuidados necessários na aproximação entre Psicologia e Literatura. 
Have you seen Dämmerung [twilight] yet?

Adorno para Benjamin, 5 de dezembro de 1934

Em um dos mais belos momentos do conto "Um coração simples", de Gustave Flaubert (1948), encontramos o seguinte trecho²:

Arrivée au sommet d'Ecquemauville, elle aperçut les lumières de Honfleur qui scintillaient dans la nuit comme une quantité d'étoiles; la mer, plus loin, s'étalait confusément. Alors une faiblesse l'arrêta; et la misère de son enfance, la déception du premier amour, le départ de son neveu, la mort de Virginie, comme les flots d'une marée, revinrent à la fois, et, lui montant à la gorge, l'étouffaient.

Segue-se a tradução, de Milton Hatoum e Samuel Titan Júnior (2004):

Chegando aos altos de Ecquemauville, Félicité viu as luzes de Honfleur, que cintilavam na noite como uma multidão de estrelas; o mar, mais ao longe, espalhava-se confusamente. Então uma fraqueza a deteve; e a miséria da infância, a decepção do primeiro amor, a partida do sobrinho, a morte de Virginie, como ondas de uma maré, voltaram de uma só vez e, subindo-lhe à garganta, sufocavam-na.

Percebemos nesta cena toda a beleza do cuidadoso estilo de Flaubert. O narrador, não nomeado, não se mostra ao leitor, e permanece deliberadamente ausente em todo o conto. É como se a história contasse a si mesma. Enquanto leitores, somos remetidos diretamente à cena, sem intermediações: vemo-la diante de nós. Acompanhamos a personagem Félicité em sua jornada no justo compasso dos acontecimentos que a envolveram.

Félicité encontrava-se no meio de uma dura viagem. Seguia a pé uma distância longa, agora um trecho de subida, submetida às baixas temperaturas de um rigoroso inverno, e acabara de ser vitimada, no caminho, em um trágico incidente; mas Félicité, acostumada às durezas da vida, mostrava-se impassível ante as dificuldades. Algo acontece, contudo, quando ela chega aos altos de Ecquemauville, que a faz sentir-se subitamente fraca. Essa fraqueza a faz ceder, e interrompe sua caminhada. Uma estratégica pausa no fluxo do texto é promovida por um ponto e

2 Para as citações originais em francês utilizaremos a edição da Gallimard (Bibliothèque de la Pléiade) das obras completas de Flaubert e, para as traduções em português, as edições das brasileiras Cosac Naify (Três Contos) e da Nova Alexandria (Madame Bovary) que se encontram referenciadas ao final do texto. 
vírgula3:" Alors une faiblesse l'arrêta,". Ela encontra-se diante de uma bela e ampla paisagem: vê as luzes da cidade para onde se dirige cintilarem,e, mais ao longe, o mar, de contornos confusos, pois já anoitecera. Ao atingir um lugar alto, seu campo de visão se ampliou. Não se trata de uma pausa longa, não é um ponto final: um ponto e vírgula é praticamente o tempo de uma inspiração. Com a pequena pausa do texto, também nós, leitores, somos obrigados a nos deter; mas para ajustar o foco, diríamos em linguajar atual.Somos a partir dali direcionados para o "mundo interno" de Félicité. A nova cena parece espelhar-se na anterior. Tal sensação é reforçada pelo ritmo das frases, que se repete no primeiro período (a descrição da paisagem) e no segundo (as lembranças de Félicité), mas também pela imagem que acompanha a enumeração das tristes lembranças de Félicité, apresentada em modo crescente, comme les flots d'une marée.

As metáforas visuais desempenham um importante papel na obra de Flaubert ${ }^{4}$. Mas em "Um coração simples" elas adquirem particular relevância, tornando-se fundamentais para a compreensão do personagem, de sua história e do estilo do autor. No título mesmo do conto nos deparamos com uma bela figura de linguagem, uma antonomásia empregada em substituição ao nome de Félicité: um coração simples. Tal imagem resume em grande medida o modo como a personagem do conto será mostrada. A imagem do coração, desde a Antiguidade ${ }^{5}$,é associada a sentimentos nobres, como o amor, a paixão, a compaixão, a bondade. Por outro lado, o coração enquanto símbolo contrapõe-se à cabeça e ao cérebro, relacionados à razão, ao pensamento, à reflexão, ao planejamento, à inteligência. Todas essas características condizem com a caracterização de Félicité que se dará no conto: ela é bondosa, amorosa e afetuosa, mas, ao mesmo tempo, desprovida de inteligência, esperteza, malícia. Essas características contribuirão para realçar o virtuosismo moral da personagem, ao mesmo tempo em que oferecem ensejo para que ela esteja submetida a todo um conjunto de adversidades ${ }^{6}$. significativas, nenhum tem cesuras nervosas e variadas como as suas" (p. 102).

4 Reiteramos a importância dessas metáforas sem entrar no mérito da polêmica estética levantada por Proust (1971), para quem "il n'y a peut-être pas dans tout Flaubert une seule belle métaphore"/ "talvez não exista em toda obra de Flaubert sequer uma única bela metáfora" (p. 586).

5 Remonta a Aristóteles a ideia, já então questionada por cirurgiões gregos, de que as emoções podiam ser localizadas no coração. Interessante notar que algumas das traduções do conto para o português substituíram "coração" por "alma", talvez com a intenção de reforçar o caráter religioso e moral da personagem.

6 Baudelaire utilizava a palavra dupe, que em português quer significa "otário,"'tolo","'ingênuo" para designar o homem simplório, que se deixa enganar, e é o oposto do conhecedor da natureza humana (Benja$\min , 1989$, p. 37). 
É preciso lembrar que Flaubert vivia um momento da história francesa em que a visão enquanto sentido exercia um papel particular na maneira como se percebia o mundo. $O$ pensamento francês encontrava em suas bases o paradigma visualista de Descartes ${ }^{7}$ e de Voltaire, associando as ideias à representação interna na consciência; e os pensadores iluministas já haviam efetuado a ligação entre lucidez e racionalidade responsável por dar ao lluminismo seu nome. Paralela ao desenvolvimento do pensamento filosófico, ao longo do século XIX, uma série de transformações - decorrentes sobretudo do rápido aumento populacional verificado nas grandes cidades e do advento de um conjunto de inovações tecnólogicas - exercerá grande impacto na vida cotidiana dos franceses, afetando sobremaneira seu modo de vere apresentar o mundo por meio da arte. Dentre essas inovações, destacamos a luz elétrica, o uso da locomotiva a vapor e a invenção do daguerreótipo. Paris, a "Cidade Luz",vinha sendo progressivamente iluminada por lampiões a gás desde o início do século XIX; em 1889, às vésperas da invenção de Thomas Edison, a cidade viria a conhecer seu monumento mais expressivo, a torre Eiffel, cujas luzes podiam ser avistadas a quase duzentos quilômetros de distância. Como fruto da produção madura de Flaubert - "Um coração simples" é escrito em 1875 - o conto que estudamos aqui incorpora muito dessas influências em seu realismo. A locomotiva, desenvolvida na Inglaterra como mecanismo de extração do minério de carvão do interior das minas, ganhará enorme destaque a partir de 1825, como o grande símbolo da Revolução Industrial ${ }^{8}$, quando começa a ser utilizada para o transporte desse mesmo carvão aos portos e às indústrias e, na sequência, para o transporte de passageiros. Na França, em 1850, o país já contava com pelo menos uma dúzia de estradas de ferro. $O$ daguerreótipo, protótipo da fotografia criado por Louis Daguerre, fora inventado no ano de 1837. Em 1856, Tournachon, conhecido como Nadar, que por meio de uma iluminação artificial já registrara imagens das catacumbas de Paris, faria a primeira fotografia aérea da cidade a bordo de um balão (em 1861 a fotografia aérea seria logo usada como arma de guerra). Se a locomotiva promovia, por meio de seu deslocamento veloz, uma rápida mudança de referencial do viajante ${ }^{9}$, desorientando a perspectiva cartesiana, a câmera fotográfica, por sua vez, validava uma concepção de perspectiva identifi-

7 Apoiado em diversos comentadores, Martin Jay colocará Descartes como um dos fundadores de uma tradição especulativa reflexiva, calcada no sujeito do conhecimento (Jay, 1994, p. 70).

8 Para Hobsbawm (2007):"Nenhuma outra inovação da revolução industrial incendiou tanto a imaginação quanto a ferrovia, como testemunha o fato de ter sido o único produto da industrialização do século XIX totalmente absorvido pela imagística da poesia erudita e popular" (p. 71).

9 Para Ginzburg (2002), a experiência da viagem de trem está associada ao que ele considera o "estilo quebrado" de Flaubert (p.112). 
cada com a visão em si, operada após o Quattrocento (Jay, 1994, p. 127). Tais transformações concatenavam-se perfeitamente às pretensões realistas.

Ainda que Flaubert não nutrisse apreço especial pela fotografia, antes, a considerasse sob o crivo do ridículo uso burguês que começava a ser feito dos retratos ${ }^{10}$, seu realismo contém muito dos elementos que compõem o modo de ver do século XIX, que ele buscará registrar à moda de um filmmaker (Spiegel, 1976, citado por Jay, 1994, p. 111) dos dias de hoje, concentrando em sua obra de ficção os acontecimentos de seu tempo, tal qual eles se mostravam a ele. Ou, nas palavras de Auerbach, tal como eles apareceriam a Deus (Auerbach, 2004, pp.319, 436). Se as concepções ocidentais de tempo e história, como Auerbach nos mostra, estão profundamente articuladas com o cristianismo, Flaubert faz jus a seu papel em mais de um aspecto. Ao assumir, à sua maneira, o Realismo enquanto missão quase mística contribui não apenas para a consolidação do romance como gênero literário, mas da própria Literatura, alçada à categoria de irmã da História, dando, sob novos contornos, prosseguimento ao projeto romântico, que já substituíra a Literatura à Retórica - as figuras de linguagem em lugar dos tropos. É com devoção religiosa que Flaubert se aferrará à nova empreitada literária: os subtítulos de Madame Bovary -"costumes de província" - e Educação Sentimental - "história de um moço" - denunciam sua intenção de registro histórico, enquanto o tema de todos os seus Três Contos, dentre os quais está"Um coração simples", dirão respeito a uma espécie de atualização de valores religiosos e/ ou de hagiografias ao olhar secularizado de seu tempo.

Buscando o máximo de objetividade em seu estilo particular, Flaubert dava um passo além de outros escritores realistas, como Balzac e Stendhal, procurando fugir à intromissão voyeurística do narrador na vida de seus personagens, resistindo mesmo à interiorização em si (Genette, 1966, citado por Ginzburg, 2002, p. 108). Tal resistência ganha maiores proporções ao longo da escrita de Flaubert, tornando-se bastante evidente em uma produção madura como "Um coração simples". Esse desejo de objetividade o levará a priorizar o uso de primeiros planos ${ }^{11}$ - exce-

10 Em seu ensaio "Repúdio à fotografia", Oehler (2004) analisa a associação entre fotografia e procriação em Flaubert. Além de pesquisar as opiniões de Flaubert sobre a daguerreotipia em sua correspondência, também faz uma interessante análise do modo como a fotografia comparece em Madame Bovary: no romance, Flaubert ridiculariza o gesto de Charles de fazer um retrato de si mesmo para dar a Emma, que não o amava e já consumara àquela altura duas traições. Um sentido para a paradoxal aversão de Flaubert aos retratos, Oehler encontra em Benjamin:“O homem foi feito à imagem de Deus, e a imagem de Deus não pode ser fixada por nenhum mecanismo humano"' (p. 230).

11 Na verdade, diria Moretti (2003), em relação aos romances do século XIX, não se trata de uma predominância do primeiro plano, mas do pano de fundo alçado à categoria de primeiro plano. Voltaremos ao assunto adiante. 
ção feita, neste caso, à bela cena que encerra o conto, quando a agonia de Félicité acompanha paralelamente o desenrolar da procissão religiosa que adentra no pátio da casa. A vida de Félicité é narrada como um continuum de acontecimentos, de modo linear - o que é expresso pelo uso do imparfait como tempo verbal predominante. A estrutura de seu texto é composta majoritariamente por frases curtas, à moda de notícias ${ }^{12}$. Flaubert evita o uso de advérbios, bem como o uso de adjetivos que tragam uma conotação pessoalizada, subjetiva, ao texto. Suas descrições, bastante detalhadas - o que enfatiza seu efeito de real, segundo Barthes (1972) -, recebem grande destaque, colaborando para realçar o caráter cotidiano de suas histórias.

A pontuação muito presente torna seus textos, como diria Proust (1971), repleto de espaços em branco. Se quisermos avançar um passo, poderíamos dizer que suas frases curtas, bem pontuadas, carregadas ao mesmo tempo de imagens e espaços vagos oferecem-se às projeções do leitor. Não se trata, porém, de uma leitura a ser feita all'agio daquele lê, pois a mesma pontuação precisa que descortina as imagens associadas ao texto também impõe um ritmo de leitura. Somos assim transportados pelo texto de Flaubert, conduzidos na velocidade estabelecida por ele, fazemos juntos as devidas pausas. Esse ritmo, entretanto, não aparece como arbitrariedade do autor, senão como imposição dos próprios acontecimentos que ele se dispõe a narrar, o que realça a impressão de estarmos colados à cena, presentificada diante de nós. Somos apresentados aos personagens, principalmente, a partir de uma caracterização exterior, e lhes conheceremos o caráter através do desenrolar continuado de suas ações ao longo da história.

Os acontecimentos da vida de Félicité são uma sucessão de perdas e substituições. Os pais morrem enquanto ela ainda é uma criança, e sua família se dispersa. Abrigada em uma granja, sofre com os maus-tratos e, mesmo sem reagir a eles, acaba expulsa. Passa a trabalhar em outra granja, até que, já adolescente, apaixona-se por Theodore. Mas é abandonada por ele, que opta por casar-se com uma mulher rica. Chegando à casa da Sra. Aubain, apega-se às crianças, particularmente à menina Virginie. Contudo, a Sra. Aubain envia Virginie a um internato para educá-la. Tendo em seguida reencontrado a irmã, por um acaso, durante um veraneio no mar, Félicité pede permissão para receber em casa seu sobrinho Victor. A decisão de receber em casa o sobrinho, após a partida de Virginie, como ela própria anuncia, visa preencher-lhe a falta que sente da filha da Sra. Aubain - falta que em certos momentos parece não ser mais do que uma sensação de tédio. $O$ menino cresce, e a convivência entre eles aumenta:Victor

12 A literatura jornalística, sabemos, exercia grande influência sobre Flaubert, a se notar pelo fato de tanto o enredo de Madame Bovary quanto de sua obra de juventude Bibliomania terem sido extraídos de notícias publicadas em jornais impressos. 
passa a compartilhar com a tia suas experiências, traz-lhe presentes. Mas Victor, tornando-se um grumete, parte em viagem para a América. Ele acaba por falecer à chegada, vítima de um erro médico, quando recebia tratamento para a febre amarela. Morre também a menina Virginie, em seu internato. $O$ tempo passa sob o impacto de tais perdas, enquanto acontecimentos políticos da França repercutem, de forma muito indireta, no cotidiano dos personagens ${ }^{13}$. Félicité passa a cuidar de mendigos e refugiados. Com a Revolução de Julho, um novo prefeito chega a PontI'Evêque, junto com a família, um negro e um papagaio; quando partem, após a derrocada da Revolução, deixam a ave para a Sra. Aubain. Esta, por sua vez, incomodada com a sujeira da ave, acaba por dá-la à criada. Félicité apega-se ao papagaio: dá-lhe um nome, ensina-Ihe frases, cuida de suas doenças e de protegê-lo das agressões das pessoas que frequentam a casa. Mas também o papagaio acaba morrendo. Félicité não se conforma com esta última perda. Assim, atende à sugestão da Sra. Aubain de mandar empalhar o animal. O medo de perder a ave, mesmo morta, é tão grande, que ela, desconfiada da eficiência do serviço postal, decide-se a levá-lo pessoalmente até o porto de Honfleur, de onde a ave seria despachada. A chegada aos altos de Ecquemauville acontece durante essa viagem.

É possível estabelecer uma linha descendente do apego de Félicité em relação a esses personagens. Seu primeiro objeto de amor é o jovem Theodore, cujo nome, de origem grega, significa "enviado por Deus". Perdido, contudo, seu grande amor, e já em casa da Sra. Aubain, Félicité se apega à menina Virginie, que ela mesma descreve como "feita de matéria preciosa".Victor, um grumete, substitui-se a ela, e morre como"mais um" ambiguidade entre a condição de um reles aprendiz de marinheiro, equivalente à condição de Félicité, como apenas "mais uma" criada, e o lugar genérico na sucessão de objetos involuntariamente descartáveis aos quais ela se dedica. Às crianças, seguem-se o mendigo (pai Colmiche), os soldados, doentes e refugiados, a quem, contudo, em sua generosidade aleatória, ela já não é mais capaz de amar individualmente. Assim, termina por recusar a proposta de casamento de um refugiado polonês, porque ele avançara sobre uma salada guardada. No nível mais baixo de sua escala de afetos, ela terminará então por dedicar-se ao papagaio que lhe fora doado, Loulou.

Se ela não podia já relacionar-se com as pessoas enquanto pessoas, senão como objetos, ao papagaio ela devotará, contudo, um amor como que relacionado "a um filho, ou a um namorado."Um papagaio não pode voar, ele não poderia partir. Entretanto, ele foge. É quando Félicité adoe-

13 Em "Um coração simples", como na Educação Sentimental, nem as revoluções são capazes de alterar o ritmo inercial dos acontecimentos (Moretti, 2003, p. 14). 
ce, como que se dando conta de que até mesmo o animal poderia abandoná-la.O papagaio retorna, mas morre em seguida. Ao empalhá-lo, ela assegura-se de sua perenidade. $O$ animal torna-se verdadeiramente objeto, no sentido literal da palavra, e a este objeto o amor de Félicité se volta com todo fervor. Por fim, sacralizado em meio à confusão religiosa de Félicité, o papagaio se converterá, no momento de sua morte,em mera imagem, associado à imaterialidade do Espírito Santo, que ela se mostrava incapaz de compreender.

No mesmo passo em que seus objetos de amor descem de grau, contudo, há um movimento contrário de ascensão no conto:a expansão do coração de Félicité. Expansão esta que encontrará seu clímax na apoteose final do conto. Seu amor cresce, e ela se torna progressivamente mais generosa. Essa generosidade assume proporções ainda maiores após o episódio em que a Sra. Aubain, durante a limpeza do quarto da falecida Virginie, concede um primeiro e único abraço à carente Félicité. Esse movimento de expansão não é, contudo, desprovido de crítica, e sua positividade é relativizada quando Flaubert caracteriza a bondade ampliada por gratidão à Sra. Aubain como dévouement bestial et une vénération religieuse. Trata-se de um movimento ambíguo, portanto. $O$ coração se expande, mas o círculo de suas ideias, como se verá mais tarde, se encoIhe. No mesmo passo, tais movimentos acompanham a decadência física de Félicité, conduzindo a história, pouco a pouco, à sua extinção (Titan Júnior, 2004, p. 9).

Enquanto leitores, sentimo-nos mais próximos a ela. Essa sensação é enfatizada no momento em que se dá a conhecer o quarto de Félicité, que não fora ainda apresentado ao longo da história:" Cet endroit, où elle admettait peu de monde, avait l'air tout à la fois d'une chapelle et d'un bazar, tant il contenait d'objets religieux et de choses hétéroclites" ${ }^{\prime \prime 4}$. Somos admitidos ao aposento íntimo da personagem, não por acaso, quando este passará a servir de abrigo para o papagaio Loulou devidamente empalhado.

A descrição do quarto de Félicité é surpreendente. São expostos em sequência todos os objetos que ela ajuntou ao longo de sua vida como recordações de pessoas e ocasiões especiais: a caixinha dada de presente por seu sobrinho, o chapeuzinho de pelúcia de Virginie, assim como uma grande quantidade de objetos aparentemente desprovidos de sentido. A "abertura" do quarto, já no final do conto, assume o aspecto de uma revelação. Por meio de seu hábito de colecionar objetos, descobrimos um traço importante da personalidade de Félicité. O narrador continua oculto sob o discurso, mas seu julgamento transparece por detrás da

14 "Esse lugar, ao qual admitia poucas pessoas, tinha um ar ao mesmo tempo de capela e de bazar, tantos eram os objetos de culto e as coisas heteróclitas que continha" (grifos nossos). 
pretensa neutralidade, como evidenciam o uso do ponto de exclamação e os comentários inseridos na frase:

sur la commode, couverte d'un drap comme un autel, la boîte en coquillages que lui avait donnée Victor; puis un arrosoir et un ballon, des cahiers d'écriture, la géographie en estampes, une paire de bottines; et au clou du miroir, accroché par ses rubans, le petit chapeau de peluche! Félicité poussait même ce genre de respect si loin, qu'elle conservait une des redingotes de Monsieur. Toutes les vieilleries dont ne voulait plus Mme Aubain, elle les prenait pour sa chambre. ${ }^{15}$

O hábito de Félicité de conservar tantos objetos estranhos e inutilmente assume ele mesmo um caráter estranho, anormal, "tão longe" ela leva "essa espécie" de respeito. No entanto, o fato não merece qualquer discussão na história, nem por parte do narrador, nem dos demais personagens. Permanecemos, como leitores, tomados pelo estranhamento diante da cena.

Walter Benjamin (2007), em sua obra das Passagens, caracteriza o colecionador como um alegorista. Para ele:

Pode-se partir do fato de que o verdadeiro colecionador retira o objeto de suas relações funcionais. Esse olhar, porém, não explica a fundo esse comportamento singular.... para o colecionador, o mundo está presente em cada um dos seus objetos e, ademais, de modo organizado. Organizado, porém, segundo um arranjo surpreendente, incompreensível para uma mente profana.... Basta que nos lembremos quão importante para o colecionador é não só seu objeto, mas também todo passado deste, tanto aquele que faz parte de sua gênese e qualificação objetiva, quanto os detalhes de sua história aparentemente exterior. (p. 241) ${ }^{16}$

No gesto de retirar os objetos de seu contexto, o colecionador recria a história, à moda de um grande enciclopedista.Torna-se, segundo as palavras de Benjamin, um fisiognomonista do mundo das coisas, capaz de enxergar-lhes o destino em sua história do mundo. Reunindo tantos objetos fragmentários, com os quais preenche seu quarto, Félicité busca alcançar a unidade necessária para que sua própria vida faça sentido.

15 "sobre a cômoda, coberta por uma toalha como se fosse um altar, a caixa revestida de conchas que Victor Ihe dera; mais um regador e uma bola, cadernos de caligrafia, o atlas com gravuras, um par de botinas; $\mathrm{e}$, no prego do espelho, atado pelas fitas, o chapeuzinho de pelúcia! Félicité levava essa espécie de respeito tão longe que conservava uma das sobrecasacas do patrão. Todas as velharias que a Sra. Aubain não queria mais, ela as levava para o quarto."

160 próprio Benjamin adota a coleção de fragmentos como método para a elaboração de sua obra Passagens. 
Tal unidade parece expressa na figura do papagaio.É para ele que se abre o quarto de Félicité. Para além de mais um objeto de apego, o papagaio concentrará em si os demais objetos que se foram, transmutados em uma forma que os aproxima do sagrado e do amor universal de Deus. Interessante lembrar que já no início da história, enquanto acompanhava as aulas de catecismo de Virginie, Félicité encontrava nas histórias do Evangelho os mesmos objetos presentes em sua vida de cria$\mathrm{da}$, como se Deus os houvesse santificado (parece-nos ouvir os ecos do discurso da Reforma, a santificação pelo trabalho...). Originário das Américas em sua história terrena, o papagaio a fazia recordar do sobrinho Victor.

Para nós, leitores, a figura do papagaio parece imersa em tantos ou mais mistérios e associações, principalmente se tomamos em conta que o papagaio surge na história como elo com a Revolução de 1830, aparecendo de modo súbito como um fetiche daquela. ${ }^{17} \mathrm{~A}$ alucinação de um gigantesco papagaio planando nos céus, nos momentos finais da vida de Félicité, apresenta-se, por sua vez, como negação da própria visão objetiva.

É Félicité quem nos aponta (ou o narrador que fala por ela, ela mesma desprovida de voz) o fato de que o papagaio é uma ave que fala. Por isso, sua explicação de que um papagaio seria mais adequado para representar o Espírito Santo do que uma pomba. Sabemos, contudo, que o papagaio não fala, apenas repete... O papagaio, assim, como um kitsch do kitsch de uma imagem de Épinal, destaca-se em meio à profusão de objetos empilhados, e nos faz pensar na própria Félicité como uma cópia de si mesma, no meio de sua coleção.

A história de Félicité está profundamente ligada à sua condição social de criada. A primeira frase do conto, reveladora do esmero formal do autor, nos fornece com poucas palavras uma grande quantidade de informações:" Pendant un demi-siècle, les bourgeoises de Pont-l'Evêque envièrent à Mme Aubain sa servante Félicité" ${ }^{\prime 18}$. Não somos apresentados diretamente à protagonista, que nos é introduzida por meio das bourgeoises de Pont-l'Êveque, sujeito da oração. Estas, por sua vez, não invejam Félicité, mas a sorte da Sra. Aubain, sua patroa, que a possui como criada. Reafirma-se aí o ponto de vista a partir do qual a conheceremos. E também o período de tempo importante para a história: quase toda a vida da personagem, o que significa o período em que Félicité trabalhou

17 Ao tratar das imagens descritas durante o que chama de "idílio de Fontainebleau" na Educação Sentimental, e de sua relação com a Revolução de 1848, Oehler (1999) afirmava:"As metáforas nos textos de Flaubert possuem a vantagem de prestarem-se tão bem a uma leitura a-histórica, vagando ao sabor do sonho, quanto a uma impassível, voltada para o contexto" (p. 323).

“Durante meio século, as burguesas de Pont l'Évêque invejaram à sra. Aubain sua criada Félicité." 
na casa da Sra. Aubain, com uma breve introdução - assim como em Madame Bovary, a vida de casada de Emma, com uma breve introdução, e, na Educação Sentimental, a vida adulta de Frédéric, com suas experiências sentimentais e urbanas. ${ }^{19}$

Todo o primeiro capítulo é dedicado à apresentação, não apenas de Félicité, mas, com grande relevo, de sua patroa, e da casa em que viveram. Tomamos conhecimento de sua rotina de trabalho e de todas as vantagens pelas quais ela gera inveja a outrem: ela custa pouco cem francos ao ano; come pouco-, seu pão dura vinte dias; trabalha muito e todo o dia; é fiel à patroa; e, por fim, atuava como une femme en bois, fonctionnant d'une manière automatique ${ }^{20}$. A imagem corresponde às características de uma máquina.

Entre a Sra. Aubain e Félicité é estabelecido um jogo de oposições. Se a Sra. Aubain será invejada por sua criada, Félicité, por sua vez, não terá nenhuma vantagem evidente com a parceria. Conviverá com a Sra.Aubain, que não é uma pessoa amável, em uma casa sombria e empobrecida, com aposentos sem música e cheirando a mofo, empenhando obstinadamente sua força física na realização dos trabalhos da casa.Tal esforço não se dará impunemente, o que, somado às desventuras que Félicité sofre ao longo da vida, transparecerá em seu envelhecimento precoce, até o momento em que ela já não aparenta plus aucun âge. Enquanto Félicité trabalha desde o nascer do sol até o anoitecer, sem interrupção, a Sra. Aubain, em seu soggiorno ${ }^{21}$, recebe os amigos, vê as horas passar, tricota a lã que Félicité fiou.

Da Sra. Aubain não saberemos o primeiro nome até o final do conto. Ainda que sua personagem seja relevante, não é possível estabelecer uma relação íntima com ela. De Félicité, ao contrário, não conheceremos o sobrenome, senão de forma indireta, apenas ao final do segundo capítulo, quando ela se reencontra com a irmã, Nastasie Barette. A patroa, fria, organizada e de natureza pouco expansiva, participa da administração dos bens da família, ao lado do Sr. Bourais (que mais tarde revelará sua picardia), e não hesita em apartar-se dos filhos quando necessário, ainda que lhe doa. A criada, por seu turno, é emotiva, corajosa e afetuosa, abraça a patroa, chora ante suas perdas, é repreendida por beijar demasiadamente as crianças, mas, ao mesmo tempo, é desajeitada, excessivamente

19 Se Balzac voltava-se para o passado, contando sobretudo histórias de homens velhos, que já não tinham poder de alterar sua história, Flaubert amplia a abrangência temporal de sua narrativa, ocupando-se mais, portanto, do modo como essa história se constrói. Isto ainda não o torna menos passivo perante seu objeto, mas contribui um ponto para aproximar sua narrativa da literatura moderna.

20 "uma mulher de madeira, funcionando de maneira automática"

21 A sala de estar, lugar dedicado à fruição do novo bem de que passara a dispôr a burguesia: o tempo livre (Moretti, 2003, p. 15) 
crédula e, sem ter recebido nenhum tipo de educação, é incapaz de ler, de compreender as aulas de catecismo, de entender a escala de um atlas.

Félicité não possuía existência pública. Ao contrário da Sra. Aubain, que recebia os amigos, trocava visitas com a família do prefeito. Quando a menina Virginie frequenta um curso de catecismo, destinado a preparála para a cerimônia organizada especialmente para a primeira comunhão, Félicité ouve as aulas ${ }^{22}$ na qualidade de acompanhante, no fundo da igreja, e receberá sua comunhão apenas depois da cerimônia das crianças, sozinha, num espaço reservado da sacristia. Tal reprodução, obviamente, não terá o mesmo gosto da cerimônia que se realizará com toda pompa na nave central da igreja. Somente por meio de sua identificação com a menina é que ela experimentaria, então, as delícias do ritual. Se na relação com as pessoas Félicité encontrava-se presa na engrenagem mecânica das falsas equivalências, que a leva a substituir um objeto de amor por outro, ela encontra realização afetiva e existência pública justamente por intermédio de sua identificação com outras pessoas e objetos.

Do mesmo modo, será vedado a Félicité compartilhar sua aflição pela viagem do sobrinho Victor e, depois, externar a dor sentida com sua morte. Apenas quando da morte de Virginie, cujo luto receberá espaço necessário por força do luto comum à Sra. Aubain, ela poderá velar um corpo, seguir um cortejo, cuidar de um túmulo, e receber um único abraço - acontecimentos vivenciados por ela, então, como se estivessem referidos, ao mesmo tempo, tanto à morte de Virginie quanto à morte de seu sobrinho.

A rigidez de Félicité, associada à imagem de uma mulher de madeira no início da história, é construída ao longo de sua vida de criada, e refere-se não apenas à personagem em si, mas ao próprio papel social que ela incorpora. Flaubert demonstra sua intenção em retratar a vida de uma criada nos diversos momentos em que generaliza a experiência de Félicité, de modo que seu conto acabe por merecer interesse não apenas literário, mas antropológico. Isso transparece na associação do artigo indefinido a Félicité, que se realiza em diversos momentos do conto, e torna-se evidente também na medida em que Flaubert dá à sua protagonista nome idêntico ao da criada de Emma, em Madame Bovary. A maneira como Flaubert nos conta a história de Félicité torna-se então reveladora também de uma determinada visão de classe.

Embora, a rigor, fosse possível enquadrar Flaubert no que desde 1812 já se convencionara chamar de "classe média", é preciso notar que Flaubert não era um burguês em sentido estrito, isto é, suas rendas não

22 Destas aulas, conforme anotado, virão as primeiras imagens do sagrado elaboradas por Félicité, descritas com delicadeza, que serão utilizadas posteriormente nas intrincadas associações construídas para ela por Flaubert. 
provinham de qualquer atividade típica da burguesia, do comércio ou da empresa industrial.Como pequeno proprietário da província, vivendo das rendas de suas posses, ele encontrava-se mais próximo dos interesses de um pequeno estrato da nobreza que, desprovida de poder político e das antigas benesses de seus títulos, via-se agora frente à necessidade de disputar com a burguesia os cargos que lhe davam acesso à máquina pública (Hobsbawm, 2007, p. 268). Encontramos exemplo da avidez com que se lançava a essa disputa por cargos públicos nas páginas de Educação Sentimental, quando diversos de seus personagens, dentre os quais o próprio Frédéric, lançam candidatura ao parlamento ou decidem aproximar-se do poder instituído como forma de garantir salvaguarda financeira. É possível localizar aí uma das raízes do ódio declarado de Flaubert à burguesia. Se, por um lado, então, Flaubert procurava diferenciar-se dos burgueses, ele mesmo na condição de um young man of provinces ${ }^{23}$, guardadas as devidas proporções, por outro ele estava bem longe de poder ser considerado um socialista.

Em 1875, ano em que Flaubert começa a escrever seus Trois Contes, a França já atravessara três conturbados períodos revolucionários desde a Revolução Francesa, em 1830, 1848 e 1871. Em todas essas revoluções as massas de trabalhadores mais ou menos organizadas haviam se imposto como um relevante ator político, gerando renovadas preocupações para as classes dominantes ${ }^{24}$. Se a Revolução Francesa, alterando o sistema político do Ancien Regime substituíra os súditos por cidadãos iguais em direitos (conquista que sofreria ainda muitos vaivéns ao longo da história francesa), a igualdade de fato era apenas um horizonte distante, a ser conquistado, como via possível, por meio da força. Mas, com a Comuna de Paris, os trabalhadores haviam sofrido sua mais recente derrota política. A instabilidade gerada com essas guerras não condizia com o projeto de sociedade burguês, que exigia a manutenção do direito à propriedade privada, previsibilidade política e controle social propícios a uma meIhor administração dos negócios, para o que o discurso meritocrático se impunha como ideologia. Nesse sentido, a imagem da bondade e da paixão em vinculação ao povo (e à mulher), contrabalançada por sua incapacidade administrativa - associada à razão de que se veem providos o

23 Expressão utlizada pelo crítico americano Leonel Trilling (1950), para caracterizar o tipo de personagem, característico dos romances da época, representado pelo jovem do interior que parte para os grandes centros urbanos, como Frédéric Moreau, na Educação Sentimental de Flaubert.

24 Tal preocupação conduziria Gustave Le Bon (1841-1931) alguns anos mais tarde, em 1895, a elaborar sua Psicologia das multidões, com o projeto de conhecê-las e controlá-las. A obra de Le Bon, posteriormente revisitada por Freud, Adorno e Horkheimer, define sob o conceito de "alma da raça" multidões culturalmente caracterizáveis, diversas das massas modernas - estas compostas por sujeitos indiferenciados e mais facilmente manipuláveis através dos meios de comunicação (Carone, 2007). 
proprietário e o burguês -, contribui para uma explicação naturalista dos sucessivos fracassos políticos das classes trabalhadoras nas revoluções de caráter socialista e, sobretudo, de sua dificuldade em manter suas conquistas. Fornece também munição para os intentos positivistas em seus projetos de investigação da natureza humana e das diferenças entre grupos sociais que ganhavam impulso.

Mas, como se a história contradissesse a si mesma, a personagem Félicité encarrega-se de mostrar a complexidade que a envolve. Sua complexidade se revela, curiosamente, na medida em que o distanciamento crítico do narrador vai se acentuando no decorrer do conto. Assim, o leitor, em “Um coração simples", é levado a identificar-se também com Félicité no mesmo passo em que deve manter uma distância segura para poder julgá-la e, eventualmente, entendê-la. Grande parte do estranhamento que sentimos frente à descrição do quarto de Félicité deve-se ao fato de que nosso olhar aproxima-se dela na cena ao mesmo tempo em que, subitamente, não nos fazemos mais representar pela personagem: Flaubert encontrara a distância justa necessária para a investigação do ser humano 25 .

A manutenção dessa distância não tornará mais fácil, porém, a tarefa de compreender o que pensam os personagens flaubertianos. Primeiramente, devido à ambiguidade intrínseca às imagens construídas por Flaubert, que se abrem às projeções do leitor (e nos impedem, a nós também como leitores, de fazer afirmações categóricas sobre os juízos expressos no conto). Mas também, e justamente, porque a origem dos discursos, sob o uso do indireto livre, mostra-se diluída. Essa indefinição empresta-Ihes uma inovadora dramaticidade. Em Madame Bovary, cujo enredo encontra grande parte de sua beleza e complexidade nas impressões e dilemas morais que cercam a personagem de Emma, é possível localizar uma profusão de exemplos em que isso se dá. Quando Emma retorna de um encontro com Léon, em uma das cenas finais do romance, ela se depara com os muros do convento onde passara sua juventude, o que a faz refletir sobre seus desejos, relembrar os acontecimentos de sua vida e questionar-se a respeito do sentimento que nutre pelo amante:

N'importe! elle n'était pas heureuse, ne l'avait jamais été. D'où venait donc cette insuffisance de la vie, cette pourriture instantanée des choses où elle s'appuyait?... Mais, s'il y avait quelque part un être fort et beau, une nature valeureuse, pleine à la fois d'exaltation et de raffinements, un coeur de poète

25 Note-se que apenas alguns anos mais tarde, em 1880, Albert Lond faria suas primeiras incursões na clínica Salpêtrière de Charcot, utilizando uma câmera fotográfica para produzir retratos da insanidade (Jay, 1994, p. 144). 
sous une forme d'ange, lyre aux cordes d'airain, sonnant vers le ciel des épithalames élégiaques, pourquoi, par hasard, ne le trouverait-elle pas? ${ }^{26}$

O parágrafo segue-se a uma frase de Emma em discurso direto, e é pleno de considerações e dúvidas cuja origem não é possível precisar. Embora pareça tratar-se de fato da voz de Emma, o que é sugerido pela própria continuidade do discurso à sua fala, o indireto livre retira essa certeza de quem lê. Poderíamos localizar sua origem apenas na própria Emma, mas também no narrador, ou mesmo nos romances que Emma lera na juventude. É como se, na verdade, houvesse emergido uma terceira voz, o que é realçado pelo uso da terceira pessoa: uma voz intermediária e quase neutra, que"dissemina por toda a parte a master voice do narrador" (Moretti, 2003, p. 32). Essa diluição termina por dar a impressão de que, na verdade, talvez já não se trate da voz de nenhum deles individualmente, mas, sob o nivelamento operado, apenas da voz do"contrato social".

Félicité não enfrenta dilemas morais. Ao contrário de Emma, suas ações são marcadas pela certeza e retidão de caráter. Seus pensamentos, muito claros, são apresentados também de forma clara por Flaubert. Alguns dos melhores exemplos da dificuldade em precisar a origem dos discursos de "Um coração simples" podem ser encontrados na própria caracterização da personagem efetuada ao longo da história - que se sustenta, em grande medida, na curiosidade que a personagem desper$\operatorname{ta}^{27}$. Assim, quando o narrador qualifica a devoção que Félicité dedicará à patroa, por exemplo, tal impressão apresenta-se como evidente:"Félicité lui en fut reconnaissante comme d'un bienfait, et désormais la cherti avec un dévouement bestial et une vénération religieuse ${ }^{\prime 28}$. Mas uma metáfora depreciativa interpôs-se ao discurso. Poderia tratar-se de uma impressão compartilhada por qualquer um dos personagens da história, pela Sra. Aubain, pelas burguesas de Pont-l'Evêque, ou unicamente pelo narrador. Não parece uma qualificação que Félicité atribuiria a si própria. No entanto, mais adiante, Félicité, já padecendo de delírios auditivos em função de sua surdez, ouviria a voz da patroa recriminando-a:"Mon Dieu!

26 Não importa! ela não era feliz, nunca o fora. De onde vinha então aquela insuficiência da vida, aquela repentina podridão instantânea das coisas em que se apoiava?... Mas, se houvesse em algum lugar um ser forte e belo, uma natureza intrépida, cheia ao mesmo tempo de exaltação e de refinamento, um coração de poeta sob a forma de um anjo, liras de cordas de bronze, enviando para o céu epitalâmios elegíacos, por que não poderia ela encontrá-lo por acaso?

27 Coerente com a observação de Moretti (2003), segundo quem o estilo analítico-impessoal (que podemos aqui atribuir a Flaubert) "emerge não tanto na história, mas nas descrições" (p. 23, itálicos do autor).

28 "Félicité sentiu-se grata, como por uma dádiva, e desde então cuidou dela com devoção bestial e veneração religiosa". 
comme vous êtes bête!" ${ }^{\prime 29}$.Tudo indica que, àquela altura, Félicité já internalizara os discursos tecidos a seu respeito. Mas não sabemos até que ponto trata-se realmente de uma ilusão.

Assim operam os discursos ideológicos, para os quais a técnica do discurso indireto livre concedia agora expressão formal. Para emprestar mais uma vez as palavras de Moretti, o nivelamento dos discursos operado acabou por tornar secundária a preocupação mesma tanto com a voz do narrador (devidamente empurrado para as margens do quadro) quanto com a origem dos discursos, uma vez que a doxa já se encarregara de fazer subsumir os espíritos individuais.

Para o leitor, resta a "estranha incerteza de juízo", lançado para uma outra condição, não mais de destinatário primordial do discurso, mas para a"posição de um terceiro, de um não iniciado que, diante de uma realidade de significado estranho, tem ele próprio de encontrar as questões que Ihe revelam para qual percepção do mundo e para qual problema humano a resposta da literatura encontra-se voltada" (Jauss, 1994, p. 57).Tarefa nada simples, se o próprio escritor, devidamente amarrado nas teias da objetividade, deixou de existir para ceder lugar à obra autônoma. Em outros termos, a objetividade ganha a cena na escrita flaubertiana de “Um coração simples" não porque ela em si tenha aumentado de tamanho, mas porque a própria subjetividade, no rápido correr do século XIX, diminuiu - como atesta a própria necessidade de se passar a falar em "subjetividade" de um modo objetivo.

É uma conquista do romance realista, mostra-nos Auerbach (1963, p. 276), a mimesis da realidade cotidiana. Foi Victor Hugo e sua escola literária o responsável, por volta dos anos 1830, de declarar guerra à estética clássica, calcada em uma separação nítida do estilo sublime e trágico de qualquer contato com a vida presente; seu princípio da mistura de gêneros, embora ainda de modo superficial e teatral, passava a permitir o tratamento sério e trágico da realidade cotidiana, em todas as suas extensões humanas, sociais, políticas, econômicas e psicológicas. Com Stendhal e Balzac, por sua vez, a vida contemporânea e atual, com sua profundidade, dinamismo e interdependências, fará ingresso definitivo na literatura. Por meio deles, as pessoas comuns, sem distinção de posição social, poderão agora tornar-se personagens trágicos, sem a necessidade de um ambiente nobre, real ou heroico como pano de fundo. Portanto, somente no século XIX uma personagem como Félicité poderia alcançar status de protagonista.

29 "Meu Deus! Como você é burra!". Interessante anotar que, em francês, as palavras bêtise, bête e bestial possuem o mesmo radical. No incidente que atinge Félicité antes de sua chegada aos altos de Ecquemauville, ela, surda, acaba por receber uma chicotada do irritado cocheiro, porque não saíra do caminho, enfatizando mais uma vez a imagem de bestialidade/estupidez atribuída na história a Félicité. 
A imitação séria ${ }^{30}$ do cotidiano configurou-se como uma forma intermediária entre a elevação aristocrática do trágico e o rebaixamento plebeu do cômico, bastante adequada à apresentação literária de uma nova classe social - a burguesia - que também se colocava no meio do caminho entre a aristocracia e a plebe. $O$ movimento realista alcançou sua excelência com o romance francês, e teve em Flaubert um de seus maiores representantes, em função, em boa parte, da magistral análise da pequena burguesia que ele efetua em Madame Bovary. Mas, como bem nos lembra Moretti, intermediário não significa equidistante, de modo que, na medida de sua ascensão política e econômica, a burguesia, como nova classe dominante, buscará aproximar de si o mesmo estilo que antes se aparentava com a nobreza. Aquilo que ele denominará "o sério"em literatura terá por características, então, a mesma gravidade, frieza, impassibilidade e rigidez que antes se aplicavam à tragédia, usadas agora, porém, sob um novo formato.

Outras características predominantes no formato da literatura realista do século XIX podem auxiliar-nos na leitura de "Um coração simples" ${ }^{\prime \prime 3}$ : a sobreposição das descrições à narrativa, o uso do pretérito imperfeito como tempo verbal e a volumosa quantidade de "enchimentos" entre os acontecimentos relevantes da história. Essas características mostram-se profundamente articuladas com o sentido mimético que promovem. “Enchimentos", na denominação de Moretti, seriam os acontecimentos que mantêm o romance em certo grau de suspensão, sem que seus fatos ofereçam real implicação para a história ${ }^{32}$. No caso de "Um coração simples"seri am episódios como a(s) visita(s) do senhor de Gremanville, a(s) tentativa(s) de venda efetuada(s) pelos mascates, as viagens para a granja de Geffosses; é possível elencar no conto toda uma série de acontecimentos do gênero. No entanto, em algumas situações, sem que o saibamos de antemão, um acontecimento inesperado e banal dentre os demais acabará importando para os rumos da história. Assim é, por exemplo, quando, durante uma viagem para Trouville, a fim de que a adoentada Virginie pudesse tomar banhos de mar, Félicité acaba por reencontrar sua irmã, através de quem ela tomaria contato com seu sobrinho Victor. Um mero acaso em meio a uma série de eventos corriqueiros.

30 Para Moretti (2003), foi Diderot, em 1757, por meio de seus Diálogos sobre o filho natural, o primeiro a definir como "sério" o meio-termo entre os dois gêneros literários extremos, a tragédia e a comédia (p. 21).

31 Para Titan Júnior (2003), independentemente do gênero literário atribuído aos Trois Contes, eles possuem em si elementos do romance que nos permitem analisá-los sob sua ótica.

32 Moretti (2003) aponta, de forma bastante curiosa, como o romance Orgulho e preconceito, de Jane Austen, chega a comportar $97 \%$ de "enchimentos" (p. 7). 
De cada um desses episódios, obteremos informações sobre o local em que ocorrem, sobre as pessoas que o frequentam...uma grande quantidade de imagens. As descrições de Flaubert trazem imensa beleza plástica ao conto, concedem prazer àquele que lê. Fornecem verdadeiros quadros, como o que temos da casa da Sra. Aubain, da granja de Geffosses, do mar de Honfleur, dos altos de Ecquemauville, da ascensão de Loulou. Trazem o lirismo, deslocado da aventura e do inaudito para a cena na qual se desenrolam os fatos cotidianos. Mas, como bem observam Jauss e Moretti, as descrições em um texto interrompem o fluxo da narrativa: enquanto se narra não se descreve, e enquanto se decreve não se pode narrar. Isto é, as descrições contribuem para deter o curso dos acontecimentos, para retardar-lhes o ritmo, que segue lento e compassado durante o meio século da vida de Félicité em casa da Sra. Aubain.

Essas transformações assinalam uma grande virada de rumo do romance realista, na medida em que serão exatamente os elementos contrapostos aos grandes acontecimentos da história que ganharão relevo, passando a constituir a essência mesma do romance. É verdade que há também um aspecto "mercadológico" contribuindo para o inchaço das descrições e enchimentos. Em seu pioneiro estudo sobre a ascensão do romance inglês, Watts $(2007$, p. 35) aponta para o fato de que os romances mais grossos alcançavam preços mais elevados no mercado de livros, de modo que os escritores de um modo geral, não apenas os que escreviam para jornais, acabavam pressionados por seus editores para que produzissem obras de maior volume - com os quais o público burguês, aquele que dispunha de acesso econômico ao livro, poderia entreter-se, ocupar maior parte de seu tempo livre. Nesse sentido, merece destaque o fato de Flaubert, consagrado justamente por seus romances, ter se voltado com tanta dedicação e empenho à produção dos Três Contos, obras relativamente curtas, mas que consumiram cerca de um ano e meio de trabalho do autor. Porém, o fator mercado e a disponibilidade de tempo do leitor não bastam para explicar essa transformação que se verifica na forma do romance do século XIX.

Os enchimentos e as descrições adquirem espaço no romance no mesmo passo em que a vida cotidiana ganha espaço na literatura. Isto é, o fato banal e corriqueiro passou a ser também relevante: o que antes constituía apenas o pano de fundo da narrativa tornou-se a própria história, ou como dissemos anteriormente, o que era pano de fundo agora ocupa o lugar do primeiro plano, desbancando a aventura de seu posto. A regularidade da vida cotidiana burguesa, desprovida de mistérios, milagres e sobressaltos, impõe-se como forma secularizada de se contar uma história. O que torna muito apropriado o uso dos verbos no imperfeito, tempo de uma vida imperfeita, repetitiva, desapaixonada que são uma constante no conto, utilizados mesmo em episódios parti- 
culares como os que cercam a agonia de Félicité, enfatizando seu lasseamento ${ }^{33}$. Além disso, o imperfeito é também o tempo de uma vida solene, séria, grave e de caráter absolutamente privado, como adequado no imaginário burguês.

Nesse contexto, um dos aspectos mais interessantes e inovadores de "Um coração simples" será trazer para o centro da narrativa uma personagem que na vida cotidiana de seu tempo jamais ocuparia um lugar central, e que, via de regra, na produção literária de então estaria relegada a uma posição secundária, coadjuvante. Flaubert elege uma criada como protagonista, nem burguesa nem nobre, e empresta a ela toda a maestria estética de seu estilo. Desenha um belo retrato de sua existência, trazendo à luz as agruras de sua vida de servidão.

Félicité tornara-se protagonista de um conto "sério", o que nos permitirá identificar, presentes na história, elementos tanto da tragédia quanto da comédia. Como o sério não se localiza no ponto médio entre a tragédia e a comédia, tal qual notamos, é interessante atentar para o modo como elementos de ambas comparecem ao longo da história.

Como bem nos mostra Benjamin (1982), um dos aspectos que distingue a tragédia da comédia é a culpa do sujeito. O personagem trágico encontra-se enredado no destino, e as desventuras que sofre surgem na medida de sua culpa: é um herói moral (talhado, porém, na infantilidade moral, ele é incapaz de falar, e de esquivar-se, portanto, da condenação que se lhe deposita aos ombros, e que só depois de impingida o faz culpado). O personagem cômico, ao contrário, é caracterizado pela ingenuidade, pela inocência; é um homem que, nas palavras de Benjamin, facilmente definiríamos como um grosseirão. Os atos do personagem cômico não são alvo de condenação moral, interessam apenas na medida em que refletem a luz de seu caráter.

Se tivéssemos que optar entre um e outro, como classificaríamos a personagem de Félicité? Podemos qualificá-la, sem dúvida, como uma mulher grosseira - ela é desajeitada, efusiva - e ingênua; recordemo-nos da simplicidade associada a ela, que nos remete à comédia, não à tragédia, por definição urdida em uma trama complexa. Para além disso, ela é uma mulher do povo, típico da comédia. No entanto, sua história não é engraçada, não nos sentimos tentados a rir dos traços estereotipados ou ridículos de seu caráter. Os acontecimentos que a envolvem são de natureza trágica: ela perde a família, perde o grande amor, assiste a mortes

33 Há de se notar que a continuidade mimetizada em "Um coração simples", realçada pelo uso do imperfeito, é,contudo, carente de gerúndios - instrumento este que tornaria possível, mais tarde, a um escritor como Kafka defrontar-se com as incertezas e com o inacabamento, desmascarar o que se impunha como real (Carone, 2009, p. 41). 0 realismo de Flaubert não abre espaços para a incerteza, cuida, ao contrário, de evidenciar o notório - mantém o registro da opinião. 
sucessivas, sofre com os maus-tratos e a doença. Mesmo a cena da ascensão do papagaio, que em outro contexto poderíamos descrever como ridícula, assume um aspecto trágico no conto. Interessante notar, então, que Félicité não é culpada, mas, diante da sucessão de acontecimentos trágicos que a envolvem, ela age como se fosse. Ela não reage como uma vítima dos fatos, mas, ao contrário, busca ao longo da história um continuado aprimoramento moral - expande seu coração, torna-se mais generosa, como que na expectativa de fazer-se digna de uma vida melhor, que ela ainda não merecia.

Tudo isso se passa ao longo da história, contudo, sem qualquer traço aventuresco que sequer a aproxime do épico. $O$ único episódio que poderíamos qualificar como aventura no conto é aquele em que Félicité põe-se na frente do touro que os ameaçava, protegendo as crianças e a Sra. Aubain em um passeio que faziam às margens do Toucques. Episódio que, paradoxalmente, ela não considera nada especial, "mal desconfiando que tivesse feito algo de heroico". Os demais acontecimentos, incluindo aí todas as desventuras que ela viria a sofrer, não são obra de qualquer ação da personagem. Não é a ação a mola motriz do conto, uma vez que o enredo gira, de modo brilhante, justamente em torno da passividade de Félicité, de sua resignação.

A aventura começava a desaparecer do horizonte burguês, bem como do romance realista. Nos tempos modernos, a aventura se convertera na própria vida moderna, dentro das cidades que cresciam. O flâneur desaparecera, a visão tornava-se o sentido primordial para os deslocamentos do homem em meio à multidão. Se antes as pessoas protegiamse dos ataques externos, dentro da murada das cidades, agora era necessário ao homem erguer para si suas próprias muradas. Tornava-se necessário dispor de instrumentos que ajudassem os homens a conhecerem-se uns aos outros, agora que não se dispunha mais de referências pessoais que dessem conta de tanta gente, tantas instituições, tantos lugares diversos. Nessa época, aparecem os primeiros fisiognomistas (Benjamin, 1994, p. 37). Mas logo a fisiognomia de Lavater se tornará também insuficiente, ineficaz para compreender o homem e sua complexidade crescente ${ }^{34}$. A ciência voltava-se às investigações sobre a natureza humana.

Moretti diria que o acaso se substituiu ao destino no romance realista. Alguns anos depois de Flaubert, um médico vienense seria responsável por localizar o destino do homem moderno dentro dele mesmo. Depois dele, tornamo-nos todos personagens de uma tragédia, sob a inescapável saga do Édipo. 
Félicité é uma personagem emotiva, afetuosa, o que não condiz, a princípio, com a imagem de uma mulher de madeira. No entanto, a rigidez se lhe impõe, transformando-a em uma espécie de Pinocchio às avessas. O trabalho, mas também o medo, a sobriedade da Sra. Aubain, a moral religiosa contribuem para enrijecê-la. Presa em seu automatismo, Félicité acaba refém de outro círculo de repetições. Ela sofre com as sucessivas perdas afetivas, mas, para além disso, sofre com a impossibilidade de as experimentar, de erguer a voz e dar visibilidade para sua dor. Félicité é escondida, junto com seu trabalho, o que a empurra sempre para fora da cena, para fora da nave da igreja: ela chega atrasada à partida do sobrinho, encontra os amigos no lugar do noivo, perde a chance de dar seu adeus a Virginie. A ideia, externa, de empalhar o papagaio morto surge como consolo para mais uma de suas dores sem posto.

Também Flaubert enrijecera, e escondera-se nas margens das páginas. Em sua obra de maturidade, verificamos como seu estilo preciso e meticuloso tornara suas belas obras esmerados retratos.

Voltamos aos altos de Ecquemauville. Dali, do topo, o horizonte de Félicité se ampliara. Depois de tanto esforço, uma bela imagem. Ela pode ver, alcançar com olhos uma paisagem longínqua... que, na bruma da noite, apresentava-se desprovida de contornos nítidos: o mar espalhava-se, as luzes cintilavam, algo de tudo oposto a uma imagem rígida, bem definida. Pouco tempo atrás, enquanto percorria seu caminho, o cocheiro apressado devolvera-lhe, com um espelho distorcido, a imagem de uma besta, passível de ser chicoteada para fora do caminho. Agora, contudo, 0 horizonte ampliado, são os sentimentos de Félicité que se Ihe apresentam, impossíveis de deter, como as ondas do mar. Em seu momento de fraqueza, abriu-se uma brecha em suas vestes de madeira, fazendo-a ver não apenas a paisagem diante de si, o mar, as luzes e o horizonte, mas o reflexo, em sequência, dos acontecimentos tristes de sua vida, sua própria tristeza.

Podemos olhar para algo que antes não nos era dado a ver, e que se cuidava em ocultar; mas também em proteger. Algo escapara ao controle nos altos de Ecquemauville, fazendo Félicité sufocar. Contudo, anoitecera: o sol já se pôs. Àquele ponto, ela não pode mais retroceder. Seguirá viagem, com o papagaio no cesto. 
Flaubert and the subject twilight: an analysis of the tale $\boldsymbol{A}$ simple heart

\begin{abstract}
The French and World Literature have gone through an enormous transformation during the Nineteenth Century. The exquisite writing of Flaubert shows us, beyond its aesthetic importance, a new way of writing, reading and representing the man in the modern world. The careful composition of the text, using plastic images and figures of speech, in the same time that the narrator hides himself in the free indirect speech are characteristics of a Flaubertian writing. In A Simple Heart, the author introduces a portrait of Félicité, a poor woman from the countryside, virtuous model of an evanescent ethic. As he follows her in the tale through her steps and misfortunes, under a new narrator lens, we try to highlight the conditions that revolve around the appearance of a scientific-objective look to the human subjectivity, soon transformed into object of a just born Psychology.
\end{abstract}

Keywords: Subjectivity. Literary theory. French literature. Realism. Reading.

\title{
Flaubert et le crepuscule du sujet: une analyse du conte $A$ couer simple
}

Résumé: Les littératures française et mondiale ont connu une profonde transformation au cours du XIX'e siècle. L'écriture exquise de Flaubert est, par-delà de son importance esthétique, la révélation d'une nouvelle façon d'écrire, de lire et de représenter I'homme dans le monde moderne. La construction attentive du texte, l'utilisation des images plastiques et les figures de rhétoriques, tandis que le narrateur devient invisible par l'utilisation du discours indirect libre, sont caractéristiques de l'écriture flaubertienne.L'auteur nous présente dans un Cœur Simple un «portrait» de Félicité, une femme pauvre de la province en France, le modèle vertueux d'une éthique évanouissent. En suivant à travers l'histoire les étapes et les malheurs de Félicité, sous l'objective de ce nouveau narrateur, nous cherchons à mettre en lumière les circonstances entourant l'émergence d'un regard scientifique et objectif de la subjectivité humaine, bientôt transformée en objet d'une Psychologie naissante.

Mots-clés: Subjectivité.Théorie littéraire. Littérature française. Réalisme. Lecture. 


\section{Flaubert y el crepúsculo del sujeto: un análisis del cuento Un corazón simple}

Resumen: La literatura francesa y mundial han atravesado una enorme transformación durante el siglo XIX. La escritura primorosa de Flaubert nos muestra, más allá de su importancia estética, una nueva manera de escribir, leer y representar el hombre en el mundo moderno. El cuidado en la construcción del texto, la utilización de imágenes plásticas y figuras retóricas, al mismo tiempo que el narrador se torna invisible tras un discurso indirecto libre, son características de la escritura flaubertiana. El autor nos presente, en "Un corazón simple", un "retrato" de Félicité, mujer pobre del campo en Francia, modelo virtuoso de una ética evanescente. A medida que se la sigue en la historia a través de sus pasos y desgracias, bajo las lentes de ese nuevo narrador, intentamos evidenciar las condiciones en torno de la aparición de una mirada científica-objetiva de la subjetividad humana, enseguida transformada en objeto de una naciente Psicología.

Palabras clave: Subjetividad. Teoría literaria. Literatura francesa. Realismo. Lectura.

\section{Referências}

Auerbach, E. (1963). Introduzione alla filologia romanza. Torino: Einaudi.

Auerbach, E. (2004). Mimesis: a representação da realidade na literatura ocidental.São Paulo: Perspectiva.

Barthes, R. (1972). O efeito de real. In G. Genette, Literatura e semiologia: pesquisas semiológicas (pp. 35-44). Petrópolis, RJ: Vozes.

Benjamin, W. (1982). Destino e carattere. In W. Benjamin, Il concetto di critica nel romanticismo tedesco: Scritti 1919-1922. Torino: Giulio Einaudi Editore. (Edizione italiana a cura de Giorgio Agamben)

Benjamin, W. (1994a). Charles Baudelaire: um lírico no auge do capitalismo (J. Martins Barbosa \& H. Alves Baptista, trad., 3a ed.). São Paulo: Brasiliense.

Benjamin, W. (1994b). Magia e técnica, arte e política: ensaios sobre literatura e história da cultura (S. P. Rouanet, trad., J. M. Gagnebin, prefácio, 7a ed.). São Paulo: Brasiliense.

Benjamin, W. (2007). Passagens (W. Bolle, I. Aron \& C. P. B. Mourão, trad.). Belo Horizonte: Ed. da UFMG. 
Carone,I. (2007). A Psicologia das multidões de Gustave Le Bon (1841-1931): massas e poder. In Anais do XIV Encontro Nacional da Abrapso: Diálogos em Psicologia Social (pp. 5-9). Rio de Janeiro: ABRAPSO.

Carone, M. (2009). O realismo de Franz Kafka. In M. Carone, Lição de Kafka (pp. 3746). São Paulo: Companhia das Letras.

Flaubert, G. (1948). CEuvres de Flaubert. Paris: Gallimard.

Flaubert, G. (2004). Um coração simples. In G. Flaubert, Três contos (M. Hatoum \& S. Titan Júnior, trad., S. Titan Júnior, prefácio, pp. 7-12). São Paulo: Cosac Naify.

Flaubert, G. (2007). Madame Bovary. costumes de província (F.M.L. Moretto, trad.). São Paulo: Nova Alexandria.

Ginzburg, C.(2002). Relações de força: história, retórica, prova (J.Batista Neto, trad.). São Paulo: Companhia das Letras.

Hobsbawm, E.J. (2007). A era das revoluções: Europa 1789-1848(M.T.L.Teixeira \& M. Penchel, trads.). Rio de Janeiro: Paz e Terra.

Jauss, H. R. (1994). A história da literatura como provocação à teoria literária (S. Tellaroli, trad.). São Paulo: Ática.

Jay, M. (1994). Downcast eyes: The denigration of vision in twentieth-century French thought. Berkeley, CA:University of California Press.

Moretti, F. (2003). O século sério. Novos Estudos CEBRAP, 65(1), 3-33.

Oehler, D. (2004). Repúdio à fotografia. In D. Oehler, Terrenos vulcânicos (S. Titan Júnior, trad., pp. 217-235) São Paulo: Cosac Naify.

Oehler, D. (1999). O velho mundo desce aos infernos: auto-análise da modernidade após o trauma de junho de 1848 em Paris (J. Macedo, trad.). São Paulo: Companhia das Letras.

Proust, M. (1971). À propos du style de Flaubert. In Contre Sainte Beuve: suivi de Pastiches et Mélanges (pp. 586-600). Paris: Gallimard.

Titan Júnior, S. (2003). Ares de romance: realismo e gêneros literários nos Três Contos de Gustave Flaubert. Tese de Doutorado, Faculdade de Filosofia, Letras e Ciências Humanas, Universidade de São Paulo, São Paulo.

Trilling, L. (1950). The princess Casamassima. In L. Trilling, The liberal imagination: Essays on literature and society. New York: The Viking.

Watt, I.(2007). A ascensão do romance: estudos sobre Defoe, Richardson e Fielding (H. Feist, trad.). São Paulo: Companhia das Letras. 
Luciana Dadico, Doutoranda do Instituto de Psicologia da Universidade de São Paulo. Endereço para correspondência: Av. Brigadeiro Luís Antônio, 388, ap. 91,Bela Vista. São Paulo, SP, Brasil. CEP:01318-000. Endereço eletrônico: ludadico@usp.br

Recebido: 18/11/2009

Aceito: $27 / 10 / 2010$ 